\author{
DARIA KOSTECKA-JURCZYK \\ ORCID: 0000-0002-8404-7791 \\ Uniwersytet Wrocławski \\ daria.kostecka-jurczyk@uwr.edu.pl
}

\title{
Ograniczenia dystrybucji selektywnej przez platformy online - uwagi na tle sprawy Coty
}

\begin{abstract}
Abstrakt: W związku z dynamicznym rozwojem sprzedaży internetowej coraz większą popularnością cieszą się selektywne systemy dystrybucji. Jednocześnie coraz częściej w ramach tych systemów dostawcy ograniczają sprzedającym na dalszym łańcuchu dystrybucji możliwość wykorzystania internetu jako kanału sprzedaży. Takie praktyki skłaniają do pytania, czy ograniczenia kanałów dystrybucji online są dopuszczalne w świetle prawa konkurencji. Trudno jednoznacznie odpowiedzieć na pytanie, czy producent lub wyłączny dystrybutor może ograniczyć sprzedaż nieautoryzowanym dystrybutorom na niższym szczeblu rynku, zwłaszcza sprzedaż poprzez platformy internetowe należące do osób trzecich. W opracowaniu dokonano analizy selektywnego systemu dystrybucji z punktu widzenia dozwolonych ograniczeń sprzedaży głównie w oparciu o orzeczenie wstępne TSUE w sprawie Coty. Wykorzystano także orzecznictwo sądów niemieckich. W efekcie wykazano, że - co do zasady - niedopuszczalne jest ograniczanie sprzedaży przez internet, ale rezygnacja z konkretnego kanału dystrybucji online (na przykład platform należących do osób trzecich) jest możliwa.
\end{abstract}

Słowa kluczowe: prawo konkurencji, porozumienia wertykalne, system dystrybucji selektywnej.

\section{Wprowadzenie}

Komisja Europejska wdrożyła pierwsze rozporządzenie w sprawie porozumień wertykalnych nr 2790/1999 już w roku 1999¹. Liczne wątpliwości dotyczące między innymi sprzedaży internetowej przyczyniły się do jego zmiany dekadę

1 Rozporządzenie Komisji (WE) nr 2790/1999 z dnia 22 grudnia 1999 roku w sprawie stosowania art. 81 ust. 3 Traktatu do kategorii porozumień wertykalnych i praktyk uzgodnionych, Dz.Urz. WE z 1999 r., L 336, s. 21 zastąpione rozporządzeniem nr 330/2010. 
później ${ }^{2}$. Pomimo to w nowym rozporządzeniu w sprawie ograniczeń wertykalnych $\mathrm{nr}$ 330/2010 sprzedaż internetowa w ramach selektywnego systemu dystrybucji nie została precyzyjnie uregulowana.

System selektywnej dystrybucji (sprzedaży $)^{3}$ można rozumieć jako sposób organizacji łańcucha dystrybucji polegający na ograniczeniu możliwości sprzedaży określonych towarów (lub usług) nieautoryzowanym dystrybutorom na pewnym terytorium (najczęściej jest to obszar, na którym sprzedaż prowadzi dostawca). Pojęcie to zostało zdefiniowane $\mathrm{w}$ art. 1 ustawy 1 lit. e) unijnego rozporządzenia w sprawie porozumień wertykalnych a także $\S 3$ pkt 5 rozporządzenia RM z dnia 30 marca $2011 \mathrm{roku}^{4}$. Wykładnia logiczna tych przepisów pozwala uznać obie definicje za tożsame ${ }^{5}$.

Model taki stosowany jest głównie w przypadku dóbr luksusowych ${ }^{6}$ lub zaawansowanych technologicznie ${ }^{7}$, a także innych produktów wysokiej jakości ${ }^{8}$, których sprzedaż ze względu na prestiżowy charakter wymaga szczególnej „oprawy"9. Obejmuje on także produkty, które nie są luksusowe, ale producent organizuje sprzedaż selektywną, aby osiągnąć wyższą marżę zysku, próbując wykreować określony produkt w świadomości klienta jako szczególny (lepszy) ${ }^{10}$.

W selektywnym systemie dystrybucji ,zaaprobowani dystrybutorzy nie sprzedają, ani nie nabywają towarów od hurtowników lub sprzedawców detalicznych spoza oficjalnej sieci" bez względu na geograficzny zakres tego systemu. Takie podejście ma na celu uniknięcie ryzyka, że nieautoryzowani dystrybutorzy działa-

2 Notatka prasowa Komisji z dnia 28 lipca 2009 roku, nr IP/09/1197, http://europa.eu/rapid/ press-release_IP-09-1197_pl.html (dostęp: 25.03.2019).

3 Wytyczne Komisji Europejskiej w sprawie ograniczeń wertykalnych, Dz.Urz. UE z 2010 r., C 130/01, pkt 52 (dalej: wytyczne w sprawie ograniczeń wertykalnych); wyrok TSUE z dnia 13 października 2011 roku w sprawie C-439/09 Pierre Fabre Demo Cosmétique, Zb. Orz. 2011, s. I-9419, ECLI:EU:C:2011:649, pkt 54.

${ }^{4}$ Rozporządzenie RM z dnia 30 marca 2011 roku w sprawie wyłączenia niektórych rodzajów porozumień wertykalnych spod zakazu porozumień ograniczających konkurencję, tekst jedn. Dz.U. z 2014 r. poz. 1012.

${ }^{5}$ M. Marek, Wytaczenie dystrybucji selektywnej spod zakazu porozumień ograniczajacych konkurencje, „Internetowy Kwartalnik Antymonopolowy i Regulacyjny” 2016, nr 7 (5), s. 13 n.; A. Piszcz, Przeglad zmian w polskim prawie antymonopolowym w roku 2012, „Internetowy Kwartalnik Antymonopolowy i Regulacyjny” 2013, nr 2 (3), s. 4.

6 Trudno dokładnie określić, co oznacza pojęcie ,produkt luksusowy”. TSUE odniósł się do swojego orzeczenia z dnia 23 kwietnia 2009 roku w sprawie nr C-59/08 Copad/Dior, Zb. Orz. 2009, s. I-3421, ECLI:EU:C:2009:260, pkt 24, i nawiązał do bezpośredniego związku z prawem ochrony marki oraz oszacowania znanych marek poprzez wykorzystanie renomy i reputacji innego produktu.

7 Wyrok TSUE z dnia 25 października 1977 roku w sprawie 26/76 Metro I, Zb. Orz. 1977, ECLI:EU:C:1977:167, s. 1875, ECLI:EU:C:1977:167, pkt 20; wyrok TSUE z dnia 11 października 1983 roku w sprawie 210/81 Demo-Studio Schmidt, Zb. Orz. 1983, s. 3045, ECLI:EU:C:1983:277.

${ }^{8}$ Wytyczne w sprawie ograniczeń wertykalnych, pkt 185.

9 Wyrok TSUE w sprawie T-19/92 Leclerc przeciwko Komisji, Zb. Orz. 1996, s. II-1851, ECLI:EU:T:1996:190, pkt 109.

10 Decyzja Prezesa UOKiK z dnia 8 grudnia 2003 roku, nr RWR-39/2003. 
jący poza systemem dystrybucji selektywnej mogliby dokonać zakupu produktów od członków systemu selektywnej dystrybucji, a następnie odsprzedać je innym nieautoryzowanym dystrybutorom na obszarze, na którym funkcjonuje system selektywnej sprzedaży ${ }^{11}$. Powstaje jednak pytanie, czy ograniczanie możliwości sprzedaży przez platformy internetowe należące do stron trzecich (niebędących autoryzowanymi dystrybutorami związanymi z dostawcą umową) stanowi ograniczenie konkurencji w rozumieniu art. 101 ustawy 1 TFUE lub art. 6 ustawy 1 uokk.

\section{Zakaz używania platform stron trzecich a ograniczenie konkurencji}

Zakaz używania platform był już przedmiotem wielu postępowań nie tylko TSUE, lecz także sądów niemieckich ${ }^{12}$. Nie wypracowano jednak jednolitej linii orzeczniczej. W wyroku w sprawie Metro $I^{13}$ TSUE uznał, że utworzenie i działalność selektywnych systemów sprzedaży jest zgodna z prawem konkurencji, jeśli wybór sprzedającego odbywa się na podstawie obiektywnych kryteriów oraz na zasadzie niedyskryminacji ${ }^{14}$.

Inny pogląd wyraził jednak TSUE w sprawie Pierre Fabre, uznając, że ochrona prestiżowego charakteru produktu nie może tłumaczyć ograniczenia konkurencji ${ }^{15}$. Z tego należy wnioskować, że ograniczenie sprzedaży internetowej nie

11 Przeprowadzone przez Komisję Europejską badania sektora handlu elektronicznego w okresie od czerwca 2015 do marca 2016 roku pokazują, że odsetek sprzedawców, którzy zgłosili ograniczenia umowne dotyczące sprzedaży na platformach internetowych, wynosił $18 \%$. Dla porównania - najbardziej rozpowszechnione są ograniczenia cenowe (42\% przypadków). Wyniki badania Komisji wskazują, że najważniejszym kanałem sprzedaży internetowej sprzedawców detalicznych są własne sklepy internetowe. 31\% wykorzystuje dodatkowo platformy, a zaledwie $4 \%$ korzysta wyłącznie z platform internetowych; zob. sprawozdanie końcowe na temat badania sektora handlu elektronicznego, z dnia 10 marca 2017 roku, COM (2017), 229 Final, s. 12, http://ec.europa.eu/competition/ antitrust/sector_inquiry final report en.pdf (dostęp: 20.02.2019).

12 Zob. też M. Kozak, Handel online versus offline - czy rzeczywiście stare zasady ochrony konkurencji sa niewystarczające? Czy systemy dystrybucji selektywnej staty się remedium „,dobrym na wszystko"?, [w:] Wyzwania dla ochrony konkurencji i regulacji rynku. Ksiega jubileuszowa dedykowana profesorowi Tadeuszowi Skocznemu, red. M. Bernatt et al., Warszawa 2017, s. 117 n.

13 Wyrok TSUE z dnia 25 października 1977 roku w sprawie 26/76 Metro I, ECLI:EU:C: 1977:167.

14 Ibidem, pkt 20; wyrok TFUE z dnia 11 grudnia 1980 roku w sprawie 31/80 L'Oréal, pkt 15.

15 Wyrok TSUE z dnia 13 października 2011 roku w sprawie C-439/09 Pierre Fabre Dermo-Cosmétique, pkt 46-47; zob. R. Molski, Prawo antymonopolowe w obliczu globalizacji, Bydgoszcz-Szczecin 2007, s. 74 n. 
może być uzasadniane koniecznością utrzymania szczególnej „aury luksusu” przy sprzedaży markowych produktów o wysokiej jakości w każdym przypadku ${ }^{16}$.

TSUE sprzeciwił się wyraźnie argumentowi, że zakaz używania platform jest nieodzowny do zapewnienia luksusowego image produktu, ponieważ producent może stosować łagodniejsze środki i narzucić szczegółowe wymogi co do jakości, które muszą spełnić platformy należące do osób trzecich, aby sposób ich działania spełniał oczekiwania producenta ${ }^{17}$. Tutaj jest brana pod uwagę zasada proporcjonalności. Także w sklepach stacjonarnych producent może narzucić sprzedającemu swoje wymogi na przykład co do wyposażenia lokalu. Należy jednak zwrócić uwagę, że korzystanie z platform może budzić obawy o zachowanie odpowiednich wymogów jakościowych. W przypadku platform należących do stron trzecich, producent będzie zależny od tego, czy autoryzowany pośrednik zostanie trafnie wybrany i czy platforma będzie respektowała odpowiednie wymogi. Tutaj powstaje ryzyko, że nabywca w celu zwiększenia możliwości sprzedaży zbytnio kładzie nacisk na skalę sprzedaży, nie przywiązując należytej wagi do wymogów stawianych przez dostawcę. Korzystanie z platform stron trzecich przez dystrybutora ogranicza zatem możliwość skutecznej kontroli systemu sprzedaży przez dostawcę i uzasadnia wykluczenie tego kanału sprzedaży z systemu dystrybucji selektywnej.

Wyższy Sąd Krajowy w Karlsruhe w 2009 roku także uznał, że zakaz sprzedaży markowych produktów przez sprzedawcę na dalszym etapie dystrybucji nie narusza konkurencji, jeżeli dotyczy sprzedaży przez platformy należące do stron trzecich jak na przykład eBay. Sprzedający może podjąć działania, aby nie dopuścić do sprzedaży po stosunkowo niskiej cenie przez eBay ${ }^{18}$. Istotne są tutaj obiektywne kryteria wyboru platformy aukcyjnej. Dostawca może stosować zakaz sprzedaży przez platformy internetowe na zasadzie niedyskryminacji. Kryteria wyboru odsprzedających muszą być zatem tak sformułowane, aby selektywny system sprzedaży nie miał charakteru dyskryminującego. Klauzula o zakazie korzystania z platform internetowych stron trzecich może być zgodna z prawem konkurencji, ponieważ nie dochodzi do ograniczenia grupy klientów w rozumieniu art. 4 lit. b) rozporządzenia 330/2010 i tym samym nie dochodzi do istotnego ograniczenia konkurencji ${ }^{19}$.

Inny pogląd wyraził Wyższy Sąd Krajowy w Schleswigu, który uznał zakaz używania platform za niepodlegające wyłączeniu, istotne ograniczenie konkurencji. Jednocześnie nie wykluczył, że klienci jednej z platform stanowią wyodręb-

16 T. Bagdziński, Dwudziestowieczne lekarstwo na problemy XXI wieku, „Internetowy Kwartalnik Antymonopolowy i Regulacyjny" 2018, nr 2 (7), s. 127.

17 Wyrok TSUE z dnia 6 grudnia 2017 roku w sprawie C-230/16 Coty Germany, ECLI:EU: C:2017:941, pkt 56 .

18 Wyrok Sądu Krajowego w Berlinie z dnia 19 września 2013 roku w sprawie 2 U 8/09 Kart., pkt 48 .

19 Wyrok Wyższego Sądu Krajowego w Monachium z dnia 9 lipca 2009 roku w sprawie U (K) 4842/08, pkt 27, 30 . 
nioną (zamkniętą) grupę kupujących przez Internet. Ponadto za rozstrzygające uznał, że konkretne możliwości zbytu każdego ze sprzedawców będą istotnie ograniczone, ponieważ de facto zmniejszy się liczba potencjalnych klientów. Jego zdaniem, już samo sztuczne ograniczenie grupy klientów, a nie tylko wykluczenie określonej grupy, prowadzi do istotnego ograniczenia konkurencji ${ }^{20}$.

Także Sąd Krajowy w Berlinie uznał, że generalny zakaz zbytu towarów przez eBay nie zawiera żadnych cech jakościowych co do wyboru odsprzedającego - i z tego względu narusza prawo konkurencji ${ }^{21}$. Trudno uzasadnić taki zakaz, w związku z czym ma on charakter dyskryminujący. Podobny pogląd wyraża także Niemiecki Urząd Antymonopolowy (Bundeskartellamt), którego zdaniem zakaz sprzedaży przez sklepy internetowe narusza art. 101 ust. 1 TFUE i nie podlega wyłączeniu ${ }^{22}$. Taki pogląd podzielił też Wyższy Sąd Krajowy w Monachium, który uznał, że zakaz używania platform powoduje ograniczenie konkurencji i w związku z tym wchodzi w zakres zakazu zawierania porozumień ograniczających konkurencję ${ }^{23}$.

Wyrok Sądu Krajowego w Berlinie należy uznać za racjonalny w przypadku dóbr, których charakter nie uzasadnia sprzedaży selektywnej. Nie wydaje się jednak właściwe traktowanie go jako generalnej reguły pozwalającej organom antymonopolowym sankcjonować ograniczanie udziału platform stron trzecich $\mathrm{w}$ procesie sprzedaży w każdym przypadku.

\section{Orzeczenie w sprawie Coty}

Istotne znaczenie dla oceny selektywnych systemów dystrybucji w świetle prawa konkurencji i zakazu wykorzystywania platform należących do stron trzecich ma wyrok w sprawie $\operatorname{Coty}^{24}$. TSUE potwierdził w nim swoje wcześniejsze podejście do tego typu systemów sprzedaży i uznał, że zakaz używania takich platform jest zgodny z systemem sprzedaży selektywnej. Taki zakaz powinien służyć ochronie wizerunku marki. Zakaz używania platform stron trzecich umożliwia przeciwdziałanie możliwości osłabienia reputacji i prestiżu marki.

Spółka Coty Germany GmbH jest ważnym dystrybutorem luksusowych kosmetyków w Niemczech. Zajmuje się sprzedażą produktów określonych marek uznawanych powszechnie za prestiżowe w formie selektywnej, na podstawie

${ }^{20}$ Wyrok Wyższego Sądu Krajowego w Schleswig-Holstein z dnia 5 czerwca 2014 roku w sprawie 16 U Kart. 154/13, pkt 82.

21 Wyrok Sądu Krajowego w Berlinie z dnia 21 kwietnia 2009 roku w sprawie 160 729/09 Kart., pkt 38.

22 Decyzja Bundeskartellamt z dnia 19 sierpnia 2014 roku w sprawie B3-137/12 - Adidas.

23 Wyrok Wyższego Sądu Krajowego w Monachium z dnia 9 lipca 2009 roku, pkt 22.

24 Wyrok TSUE z dnia 6 grudnia 2017 roku w sprawie C-230/16 Coty Germany. 
umów o przechowanie i zarządzanie, które nakładają określone wymogi na dystrybutora. Dotyczą one między innymi zadbania o odpowiednią wiedzę pracowników o produktach lub wyposażenia punktów handlowych, co powinno podkreślać luksusowy charakter produktów. Stroną przeciwną była sieć perfumerii Parfümerie Akzente $\mathrm{GmbH}$ (dalej: Akzente), będąca od wielu lat autoryzowanym detalicznym sprzedawcą marek Coty. Jednak ta sieć nie chciała ograniczyć sprzedaży produktów nabywanych od spółki Coty przez platformę należącą do przedsiębiorcy niebędącego dystrybutorem Coty. Jednocześnie Coty dopuszczał możliwość sprzedaży przez własną stronę internetową Akzente (parfumdreams.de). Pomimo to spółka Akzente rozpoczęła sprzedaż, korzystając z Amazona, nie zwracając uwagi na fakt, że Coty zakazał swoim przedstawicielom dystrybucji przez platformy tego typu. Uznał on, że sprzedaż luksusowych kosmetyków przez takie platformy osłabia luksusowy wizerunek kosmetyków. W związku z tym Coty zaskarżył zachowanie Akzente do krajowego sądu we Fraknfurcie nad Menem. Skarga ta została jednak oddalona w pierwszej instancji ${ }^{25}$. W toku postępowania odwoławczego Wyższy Sąd Krajowy złożył wniosek o wydanie orzeczenia wstępnego przez TSUE ${ }^{26}$.

TSUE wyraził pogląd, że selektywne systemy dystrybucji wpływają na konkurencję na rynku wewnętrznym w pewnych okolicznościach, ale nie są zakazane w świetle art. 101 ustawy TFUE ${ }^{27}$. Zdaniem TSUE, utworzenie selektywnego systemu dystrybucji w celu zapewnienia prestiżu towarów luksusowych — co do zasady — jest zgodne z prawem konkurencji ${ }^{28}$. Ochrona prestiżowego charakteru powinna sprzyjać zapewnieniu odpowiedniej jakości produktów ${ }^{29}$. To jest zgodne z orzecznictwem TSUE dotyczącym prawa własności intelektualnej, gdzie jakość towarów prestiżowych sama w sobie nie jest tak istotna. Ważne jest też luksusowe eksponowanie produktów, co służy podnoszeniu prestiżu marki ${ }^{30}$.

TSUE postrzega zapewnienie odpowiedniego wizerunku marki jako uzasadniony cel ograniczenia konkurencji. Nie widzi zatem tutaj sprzeczności ze swoim

25 Wyrok Sądu Krajowego we Frankfurcie nad Menem z dnia 31 lipca 2014 roku w sprawie 2-030 128/13.

26 Postanowienie Wyższego Sądu Krajowego we Frankfurcie nad Menem z dnia 19 kwietnia 2016 roku w sprawie 11 U 96/14 (Kart.)

27 Wyrok TSUE z dnia 25 października 1977 roku w sprawie 26/76 Metro I, pkt 20; wyrok TSUE z dnia 11 grudnia 1980 roku w sprawie 31/80 L'Oréal przeciwko De Nieuwe AMCK, pkt 15; wyrok TSUE z dnia 13 października 2011 roku w sprawie C-439/09 Pierre Fabre Dermo-Cosmétique, pkt 41. Por. też wyrok z dnia 22 października 1986 roku w sprawie 75/84 Metro przeciwko Komisji (Metro II), Zb. Orz. 1986, s. I-3021, ECLI:EU:C:1986:399, pkt 40.

28 Wyrok z dnia 6 grudnia 2017 roku w sprawie C-230/16 Coty Germany, pkt 36.

29 Ibidem, pkt 28.

30 Wyrok TSUE z dnia 20 kwietnia 2009 roku w sprawie nr C-59/08 Copad przeciwko Christian Dior, Zb. Orz. 2009, s. I-3421, ECLI:EU:C:2009:260, pkt 24. Por. też wyrok z dnia 4 listopada 1997 roku w sprawie C-337/95 Parfums Christian Dior przeciwko Evora, Zb. Orz. 1997, s. I-6013, ECLI:EU:C:1997:517, pkt 45. 
wyrokiem w sprawie Pierre Fabre ${ }^{31}$, w którym potwierdza, że ochrona prestiżowego charakteru nie może uzasadniać ograniczenia konkurencji.

Treść orzeczenia w sprawie Coty wskazuje, że TSUE stara się rozróżnić towary luksusowe od innych produktów markowych. Trybunał odniósł się w nim do swojego orzeczenia w sprawie Copad/Dior ${ }^{32}$ i nawiązał do bezpośredniego związku z prawem ochrony znaków towarowych. W praktyce zwykle produkty cechujące się ,aurą luksusu” są produktami markowymi. W tym kontekście pojęcie „towarów luksusowych” należy rozumieć szerzej. Powinno ono obejmować te produkty, których luksusowa emanacja jest tylko atrybutem wykorzystywanym do oszacowania wartości znanych marek. Wobec tego przez luksusowe produkty należy rozumieć te, które są nabywane nie tylko ze względu na ich wartość materialną, ale także ze względu na ich prestiżowy charakter ${ }^{33}$.

Należy podkreślić, że TSUE w swoim wyroku rozstrzygał tylko w zakresie tego typu produktów. Badał wyłącznie te kosmetyki Coty, którym przypisano atrybuty dóbr luksusowych, i nie uwzględnił produktów, które nie były objęte pytaniem prejudycjalnym. Kryteria, które stosował TFUE do produktów luksusowych, powinny być stosowane także w odniesieniu do innych markowych towarów wysokiej jakości. Zdaniem TSUE selektywne systemy dystrybucji i zakaz używania platform stron trzecich wymuszają wysoką jakość produktów. Funkcje selektywnych systemów dystrybucji wpływają także na inne artykuły markowe - funkcja marki jest wskazówką pochodzenia produktu i tym samym określonej jakości ${ }^{34}$. Jeśli nie jest zapewniona odpowiednia jakość, wówczas osłabia się zaufanie do marki. Z tego względu niektórzy sprzedawcy produktów o wysokiej jakości stosują zakaz sprzedaży przez różne platformy w ramach selektywnego systemu dystrybucji. To jest zgodne z prawem konkurencji. Można nawet przyjąć szerszą interpretację, że zakaz sprzedaży przez platformy może być również wykorzystywany w przypadku innych produktów niż luksusowe, które są oceniane przez konsumentów jako towary wysokiej jakości, jeśli jest to uzasadnione ekonomicznie. Taką szeroką interpretację potwierdza adwokat generalny N. Wahl, który analizował nie tylko selektywny system sprzedaży towarów luksusowych, ale także ocenił zalety takiego systemu dla produktów o szczególnych właściwościach, które w opinii klientów mają wartość dodatkową (wysoką jakość) i ekskluzywny charakter.

Treść wyroku w sprawie Coty nie pozwala jednak na udzielenie jednoznacznej odpowiedzi na pytanie, czy dostawca może zakazać swoim dystrybutorom sprzedaży określonych produktów przez internet. Przede wszystkim TSUE i nie

31 Wyrok TSUE z dnia 13 października 2011 roku w sprawie C-439/09 Pierre Fabre Dermo-Cosmétique.

32 Wyrok TSUE z dnia 23 kwietnia 2009 roku w sprawie nr C-59/08 Copad/Dior, pkt 24.

33 Wyrok TSUE z dnia 6 grudnia 2017 roku w sprawie C-230/16 Coty Germany, pkt 25.

34 Wyrok TSUE z dnia 20 grudnia 2017 roku w sprawie C-291/16 Schweppes, ECLI:EU:C:2017: 990, pkt 36 . 
dokonał rozróżnienia Amazona jako platformy i jako dystrybutora. Prawdopodobnie wynika to $\mathrm{z}$ faktu, że Amazon nie jest dystrybutorem Coty. Inna jest sytuacja, gdy producent współpracuje bezpośrednio z platformą należącą do osób trzecich jako dystrybutorem, czyli gdy Amazon jest częścią selektywnego systemu dystrybucji. Wówczas zakaz sprzedaży przez tę platformę mieściłby się w zakresie zakazu $\mathrm{z}$ art. 101 ustawy 1 TFUE.

\section{Wnioski}

Ani w doktrynie, ani w orzecznictwie nie została dotychczas udzielona jednoznaczna odpowiedź na pytanie, czy w świetle prawa antymonopolowego dopuszczalne są ograniczenia sprzedaży przez platformy internetowe należące do podmiotów, z którymi dostawca nie zawiera umowy i które są wyłącznie klientami nabywcy. Powoduje to niepewność, czy utworzenie (zbudowanie) selektywnego systemu sprzedaży uwzględniające konieczność ochrony marki jest uzasadnione i dozwolone.

W sprawie Coty TSUE podkreślił, że zapewnienie ochrony wizerunku marki może stanowić uzasadniony cel ograniczenia konkurencji, z czym należy się zgodzić. Orzeczenie to niewątpliwie wzmacnia kontrolę producenta nad dystrybucją. Interesujące jest pytanie, jak rozstrzygnąłby sprawę TSUE, gdyby nie chodziło o platformę Amazon jako miejsce zbytu, ale o sprzedaż przez platformę, która wyłącznie i bez wątpienia oferuje towary luksusowe. Argument, że sprzedaż przez tę platformę osłabia luksusowy wizerunek produktu, nie byłby przekonujący. W takim przypadku trudno byłoby znaleźć uzasadnienie zakazu sprzedaży przez platformy internetowe i raczej należałoby uznać to za niedopuszczalne ograniczenie konkurencji ze względu na cel.

Powyższe rozważania skłaniają do wniosku, że w obecnym stanie prawnym przedsiębiorcy nie mają pewności, które ograniczenia sprzedaży online są dopuszczalne, a które wchodzą w zakres zakazu z art. 101 TFUE i art. 6 uokk. Należy zatem jak najszybciej dokonać rewizji rozporządzenia 330/2010 oraz wytycznych Komisji i rozważyć wprowadzenie bardziej przejrzystych kryteriów oceny dopuszczalności ograniczeń w dystrybucji online. M. Kozak sugeruje ustanowienie kryteriów de minimis dla dozwolonych ograniczeń ${ }^{35}$. Wydaje się jednak, że nie ma potrzeby wprowadzania jakichkolwiek dodatkowych narzędzi ilościowych. Przyjęty w rozporządzeniu 330/2010 próg udziału w rynku wynoszący $30 \%$ jest dosyć wysoki i należałoby rozważyć obniżenie go, ale konstruowanie dodatkowych progów obrotu wpływających na dopuszczalność pewnych ograniczeń raczej nie będzie stanowiło skutecznego remedium. Rewizja rozporządzenia

35 M. Kozak, op. cit., s. 133. 
330/2010 powinna także kłaść większy nacisk na bardziej ekonomiczne podejście w ocenie porozumień wertykalnych i zwracać uwagę na zasadność ingerencji organów antymonopolowych w tego typu ograniczenia.

\section{Bibliografia}

Bagdziński T., Dwudziestowieczne lekarstwo na problemy XXI wieku, „Internetowy Kwartalnik Antymonopolowy i Regulacyjny" 2018, nr 2 (7).

Bolecki A., Ograniczenia $w$ sprzedaży przez Internet $w$ umowach dystrybucyjnych, „Internetowy Kwartalnik Antymonopolowy i Regulacyjny”, 2013, nr 3 (2), s. 24-43.

Knibbe J., Selective Distribution and ECJ's judgment in Pierre Fabre, European Competition Law Review, 2012, nr 33 (10).

Kohutek K., Internetowa dystrybucja towarów w prawie konkurencji (ze szczególnym uwzględnieniem wytycznych Komisji do rozporzadzenia $\mathrm{nr}$ 330/2010 w sprawie porozumień wertykalnych, „Przegląd Prawa Handlowego” 2011, nr 11.

Kowalik-Bańczyk K., Internet a problematyka wspólnotowego prawa konkurencji, „Studia Europejskie" 2005, nr 2.

Kozak M., Handel online versus offline - czy rzeczywiście stare zasady ochrony konkurencji sa niewystarczajace? Czy systemy dystrybucji selektywnej staty się remedium ,dobrym na wszystko"?, [w:] Wyzwania dla ochrony konkurencji i regulacji rynku. Ksiega jubileuszowa dedykowana profesorowi Tadeuszowi Skocznemu, red. M. Bernatt, A. Jurkowska-Gomułka, M. Namysłowska, A. Piszcz, Warszawa 2017.

Marek M., Wyłaczenie dystrybucji selektywnej spod zakazu porozumień ograniczajacych konkurencje, ,Internetowy Kwartalnik Antymonopolowy i Regulacyjny” 2016, nr 7 (5).

Molski R., Prawo antymonopolowe w obliczu globalizacji, Bydgoszcz-Szczecin 2007.

Morris S.P., Vertical restrains and parallel trade: Selective distribution and Article 101 of the Treaty on the Functioning of the European Union in light of the revised rules on vertical agreements, „University of La Verne Law Review” 32, 2011, nr 2.

Piszcz A., Przeglad zmian w polskim prawie antymonopolowym w roku 2012, „Internetowy Kwartalnik Antymonopolowy i Regulacyjny” 2013, nr 2 (3).

Roszak O., Porozumienia dystrybucyjne w prawie konkurencji. Unia Europejska-Polska, Warszawa 2018.

Szmigielski A., Regulacja dystrybucji selektywnej a ograniczenia wertykalne w handlu elektronicznym w świetle unijnego prawa konkurencji, ,Przegląd Prawniczy Uniwersytetu Warszawskiego" 2016, nr 2.

Szot P., Amza A., Marketplaces restrictions and selective distribution after Coty Germany, „Yearbook of Antitrust and Regulatory Studies" 11, 2018, nr 18.

Targański B., Sprzedaż aktywna i pasywna w uslugach marketingu internetowego, „Internetowy Kwartalnik Antymonopolowy i Regulacyjny” 2013, nr 5 (2).

Wyłaczenia grupowe spod zakazu porozumień ograniczajacych konkurencję we Wspólnocie Europejskiej i w Polsce, red. A. Jurkowska, T. Skoczny, Warszawa 2008. 


\title{
Restrictions on selective distribution through online platforms - comments on the Coty case
}

\begin{abstract}
Summary
Due to the dynamic development of internet sales, selective distribution systems are becoming more and more popular. However, there is a dispute about their compliance with competition law. The problem concerns the restrictions on use of the Internet as a sales channel. In many cases, restrictions imposed by suppliers lead to questions about the permissible restrictions of distribution channels. In the light of competition law, an important problem is to find out whether the main distributor can restrict sales of unauthorized distributors, in particular sales via third party internet platforms. The study analyzes a selective distribution system from the point of view of permitted sales restrictions, mainly based on the preliminary ruling of the CJEU in the Coty case. German court case law was also used. As a result it has been shown that, as a rule, it is unacceptable to limit Internet sales, but resignation from a specific online sales channel (e.g., a third party platform) is possible.
\end{abstract}

Keywords: competition law, vertical agreements, selective distribution. 